\title{
Government Responsibility as the Main Stakeholder in Tourism Development With Collaboration Approach:
}

\author{
Literature Review on Heritage Tourism
}

\author{
Rieke Retnosary ${ }^{1,2, *}$, Nor Zafir Bt Md Salleh ${ }^{1}$ \\ ${ }^{1}$ Azman Hashim International Business School, ${ }^{2}$ Fakultas Teknologi \& Ilmu Komputer \\ ${ }^{1}$ Universiti Teknologi Malaysia, ${ }^{2}$ Universitas Buana Perjuangan Karawang \\ ${ }^{1}$ Johor, ${ }^{2}$ Kab. Karawang, ${ }^{1}$ Malaysia, ${ }^{2}$ Indonesia \\ *retnosary@graduate.utm.my, rieke.retnosary@ubpkarawang.ac.id, zafir@utm.my
}

\begin{abstract}
- currently, the economic growth of some countries is a contribution by the vast development of the tourism sector, and one of the potential destinations is heritage motivation. More than fifty-three of previous study founds five elements that associated with Heritage Tourism Development, which are four elements influencing directly and one element is impact after development as an outcome. The study is focusing on stakeholders responsibility which led by government to do the development of heritage tourism. Barriers of policies and low attention to strategic plants and policies are an influencer to the obstacles because of less attention from the leader. Collaboration approach helped government to control the system in heritage tourism process.
\end{abstract}

Keywords-stakeholders responsibility, government, heritage tourism development, strategic plan and policies, Collaboration approach

\section{INTRODUCTION}

The tourism industry has a direct impact on the development and/or economic improvement both for the government, the communities, and business community or business agency [1-3]. Schubert [4], Hsieh and Kung [1] highlighted that tourism industry provides economic growth as an engine and a vital for local economic development because there are many spillover effects of tourism such as improved Gross Domestic Product (GDP) or Gross National Product (GNP) which is important to contribute to the government as a national or regional income [5], residents economic increase [6], employment growth and job creation to reduce unemployment [4,5,7-11] and alleviate poverty [12-16] and also to recovery economic the state [17].

The tourism industry in development project has a target to be able to increase benefits for the population, improve their right attitude towards tourism in their city, and ensure a varied and sustainable tourism offer achieved in the tourist capital [6]. Tourism development is usually carried out by the government, local or state as stakeholders who are responsible for the condition of society for economic improvement. A private and resident also have the same contributions to help any development besides making profits. Like other sectors of the economy, the tourism industry faces increasingly global competition, as emerging or developing countries attract more and more tourists [18]

World Heritage Site (WHS) can play an important role as a potential tourism in promoting visitation to emerging and remote destinations. World Heritage (WH) tourism brand equity and social influence were strong positive predictors of intentions to visit WHS in the future [19]. In other words, one of tourist motivation is the heritage site perception. [20]

Serizawa and Sunami [21] defined the heritage as a process of the contemporary people engaging in the usage of the past as resources. The buildings as the tangible heritage used by the present community are combined with the actions as the intangible heritage of the people who preserve the heritage. The temporal tourists are also permitted to enjoy the process as participants. They can learn many things through their experiences at the heritage site. The social benefits reaped by the residents which are understanding the emotional engagement of tourists interacting not only with the heritage sites but also with residents allows a deeper understanding of the social impacts of tourism [22].

Nowadays, many tourists are aware of the city's status as a world heritage site that encompasses a historic centre, monuments, and architectural buildings that can be enjoyed [23]. Previous studies on development tourism site highlighted that there is positive relationship between architectural heritage, traditional customs, and folk culture and it is suggested that tourism managers and planners should consider preferring all three of these elements when developing heritage tourism site [24]. In its development, heritage tourism is usually accompanied by a supporting system such as transportation services, accommodation, security systems to make it more enjoyable for visitors and do the revisit [25]. In these situations, the authorities must do the priorities to get positive impact in promoting tourism with determine the scope of tourism development and identify the carrying capacity that is appropriate to the tourism destination to get long-term visits and eliminate obstacles that will occur in the future [26].

As known, many tourism activities are disturb by the obstacles in managerial and uncontrolled system because of the less attention from the government as a main stakeholder [27]. The obstacles such as crime, shock culture, lack of information, 
lack of facilities, water disposal problem, and many other things in the process of visitations [9,28-31]. The obstacles that interfere with tourists activities is in the process of tourism itself, and it became a significant gap between needs and expectations from tourism activities [32]. Unsupported facilities for pleasant the tourist such as safety and security system, and also external access are the major dimension in determining industrial tourism attraction which should become attention [33].

Another problems, a global problem is the lack of ownership in the sustainable in-cooperation of several smallscale accommodation companies supply businesses that are affected by four barriers, such as owner / operator knowledge, cost, lack of awareness of external forces, and availability due to location [34] and complex relationships between indigenous peoples and policymakers often become "competition" rather than collaboration to work together as a team, make this situation more difficult to equate perceptions for better development in tourism [35].

The environmental balance must be maintained, including social and cultural aspects so that it is not disrupted for present and future generations and these will be the responsibility of the stakeholders [36,14]. Considering strategic planning, planning and development processes, completing regulations, regional tourism development master plan is a must [37].

\section{A. Stakeholders}

Talking about stakeholder(s), Cambridge dictionary firstly, define as a person or group of people who own a share in a business and secondly, define as a person such as an employee, customer, or citizen who involved with an organisation, society, etc., and therefore has responsibilities towards it and an interest in its success.

In tourism, stakeholder(s) closed with second definition which are all members are connecting to have same goal on successful tourism activities. Edgell and Swanson [29] categorised the stakeholders are government as a main stakeholder, resident, private business, NGOs, and tourists. Wondirad [38] categorised the stakeholders are policy-makers, planners, destination management organizations, NGOs, private (eco-)tourism institution and local communities.

Stakeholders must be able to take actions to make the constituents can mobilise, synchronise, and synthesise their resources and efforts toward long-term tourism destination [39]. Stakeholder must collaborate to produce good cooperation and development in the tourism business [29], and the community participation is at the heart of environmental governance as it facilitates and promotes a sense of ownership in a society's decision making and social development issues [40].

Coordination between related parties has been discussed by Franz [4] about managing the tourism sector by stakeholder or governments. With this coordination, it will be useful for planning tourism facilities, managing tourism routes, and defining destination management strategies [30].

\section{MATERIAL AND METHODS}

\section{A. Systematic Literature review (SLR)}

The material for literature in this study used the online database to collected data from ScienceDirect and books.

This study used Mendeley as a readership tool [41,42] to collect data which took randomly from databased, facing help to find the scope of analysis into boundary lines of study, locating the studies with the keywords and to selection and evaluation the relevant one [43].

\section{B. Mathods}

Qualitative approach with descriptive was used in this study and simple stages was built to get systematics flow to finding issue. The stages as a bellow in figure 1:

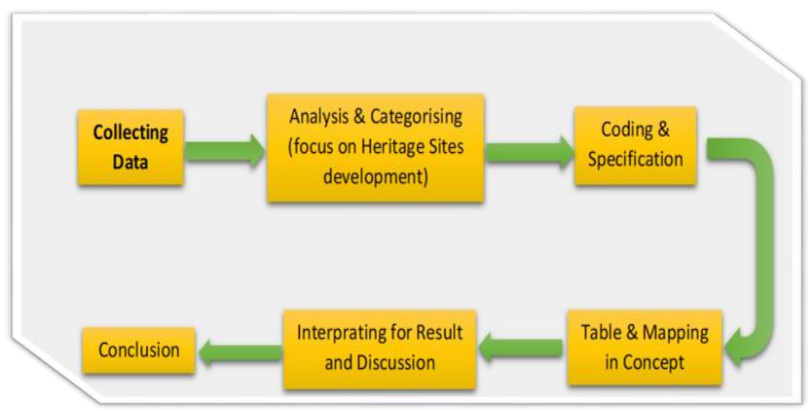

Fig. 1. Stages finding issue from SLR.

The first stage begins with data collected from the database to completed information about the issues in tourism development, especially the heritage sites. The steps were to open the database randomly then citation the studies connected with the tourism heritage development used "keywords".

Used "keywords", because of no clues or information about the author or the titles before. The words that users are "Tourism Development", "Heritage Tourism", and "Heritage Tourism Development". Then, after have read papers that already collected, searching engine more specific besides "keywords", also with the year, author from reference papers, and the titles.

Papers of the studies that have been collected, stored in Mendeley as a tool to facilitate the storage and recall of data needed.

Mendeley is a tool engine that can provide information about titles, authors, volume papers, number of issues, year, abstract, keywords, digital object identifier (DOI) by clicking one paper and easily put it into the future study as a reference.

The second stage analyses then categorized the previous studies into the few elements which connected with heritage sites development.

In the third stage, do the coded to separate the elements which directly influence the development of the heritage sites with tables to see connection and differentiation between one papers with another.

In the fourth stage, put the elements in the tables with different categories then mapping into the concept elements. Concept of Elements from SLR in figure 2. 


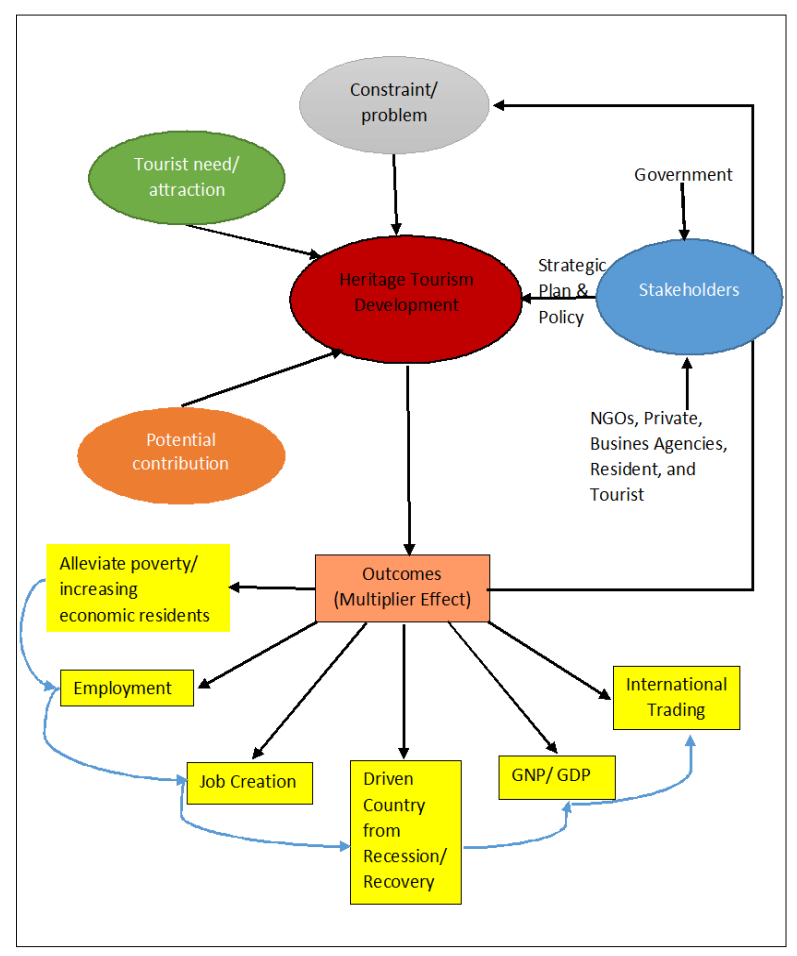

Fig. 2. Concept of Elements from SLR.

The fifth stage interpreted for description in the result and discussion. From this stage, can find the most element influenced the heritage tourism development because the studies mentioned more than the others.

In the sixth stage, do the conclusion for deliberate findings to ensure the next level of study will base on these findings and input as the right objectives.

\section{RISULTS AND DISCUSION}

Five elements as the factors that associated with heritage tourism development found in Fifty three of previous studies, which are four elements influencing directly (tourist attraction, potential contribution, obstacles, and stakeholders) and one of the elements is impact after development as outcomes or multiplier effects.

These study focused on stakeholders which have responsibility in heritage tourism development, and the descriptive explained the position of the main stakeholder in duty.

\section{A. Elements Influencing Heritage Tourism Development}

Literature review (LR) found thirty-nine from fifty-three studies as the elements of Heritage tourism which influenced heritage tourism development.

Thirty-nine studies mentioned how important to attract tourists to visits the destination and has a motive to revisits because of the offer as the potential tourism. Problems or obstacles were also recognized by the process of visits and these obstacles is very tangent with the stakeholders.

From the all elements involved, many target must be exceeded, such as hypothesis from the data said that although resident recognised the need to preserve their social and ethical values actively and to gain more revenue, but did not feel as strongly about protecting their abundant environmental resources [44]. These predicted, there is a significant gap between needs and expectation [32] from tourism activities. Model of strategic plan and policies are the important thing to keep attracting tourists, to have tourism sustainable and give the side effect to the community.

\section{B. Stakeholders' Responsibility and Collaborative Approach}

The previous studies talked about responsibilities, collaborations and contributions among stakeholders as the management actors connected with sustaining the heritage sites and the most responsibility in heritage tourism development is the government as the main stakeholder with strategic plan and policies implementation models.

Development of tourism will be in perceived with the role and responsibility of the stakeholders or government [30], and twenty-two previous studies also discussed about the important of the stakeholders $[2,4,18,14,24,26,30,45-56]$ to respond the operational of the heritage tourism destinations.

The stakeholders' element must collaborate to produce good cooperation and development in the tourism business. [29]. Stakeholders must be able to take action, to mobilize, synchronize, and synthesize their resources and efforts toward a sustainable tourism destination [39].

A collaborative approach between stakeholders managing the development of heritage must consider four values to be improved, namely, ideological barriers, different perceptions of risk, lack of sense of responsibility, ownership and commitment, and inability to adapt new situations [57].

\section{Government Responsibility as the Main Stakeholder in Heritage Tourism Development}

Tourism must have an attraction and provide a different experience. These can be done with proper promotion, coordination between related parties, such as local government, tourism, and social services, private parties engaged in tourismrelated business and the right marketing in the bidding process is crucial [29].

Inter-networking collaboration in planning and public participation and structural led-by government organized and non-governmental organizations [51].

The government must have roles for social effect and might still formulate plans intended to mitigate the burden of tourism on locals and to leverage the development of tourism [26]. Tourism development is not only an act in the field, but the use of communication technology nowadays is very helpful, such as procurement of a website where it is very important to receive input from site visitors in tourism development and also promote attractive tourist destinations [58]. The framework for the dimensions of the website is also important to attract visitors in the promotion which makes reliance on management [59].

Findings roles of government as main stakeholder are Involvement to make policy and strategic plan than operational in development [60], while the learning process for practical purposes is necessary in terms of providing new ideas to improve strategy in tourism planning (Ramanujam and 
Venkkatraman, 1987 [2,45,51] or policies to run the heritage management which has the target of tourism in region [18].

The role of heritage planning in national socio-economic, cultural and tourism policy and highlights various ambiguities in terms of concepts, objectives and approaches show gaps between rational and communicative planning ideals, between informal management systems and wider democratic concerns, and between delimited and comprehensive planning perspectives [13]. Coordination between related parties has discussed [61] about managing the tourism sector by stakeholder or governments. With this coordination, it will be useful for planning tourism facilities, managing tourism routes, and defining destination management strategies [30]. Strategic plan has a significance purposes to attract capital investment and businesses [62].

\section{CONCLUSION}

Low levels of involvement in the strategic planning process and with an emphasis on the role of political leadership and top management of organisations with a very hierarchical topdown system [45] must recognize by stakeholder especially government as a leader in development because very influence to the long-term heritage tourism destination.

Interventions by the state (government) can be important for the relative priorities given to heritage protection and tourism related economic development at heritage sites [62]. Government should be more interested and involved not only in shaping the offer of the destination but also in improving the solutions related to prevention of environment like pollution. [50].

Government as the main stakeholder led the coordination between stakeholders to heritage tourism development. Strategic plan and policies must support by NGO, Private, and Tourism and social services (business agencies), event tourists itself as the visitors which can give input which is provided the improvements to the tourism destinations (in figure 3 ).

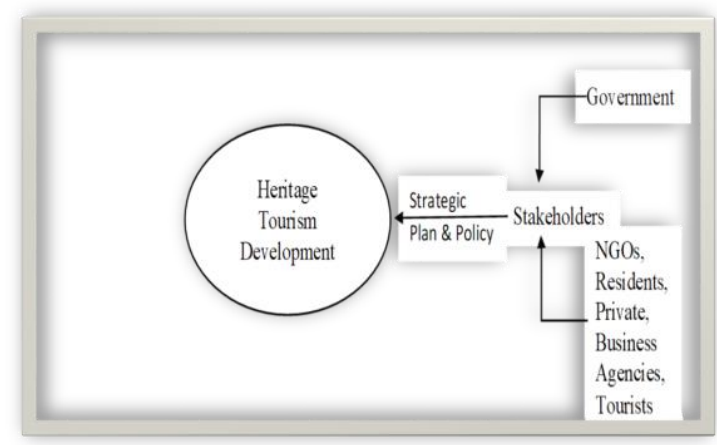

Fig. 3. Concept of responsibility stakeholder to HTD.

Multiplier effects cannot be discuss before government pay more attention to the long-term development to get long-term tourism.

Long-term tourism should thus make optimal use of environmental resources, respect host communities, and ensure variable, long-term economic operations, providing benefits that are distributed equitably among all stakeholders [14].

\section{FUTURE STUDY}

This study has a limits literature in differentiation of roles between stakeholders and main stakeholder in relationship and collaborative to investigate the implementing model of development with policy and strategic plan in many destinations related to the past, and study will continue to this level.

\section{REFERENCES}

[1] H-J Hsieh and S-F Kung, 'The Linkage Analysis of Environmental Impact of Tourism Industry' Procedia environmental Sciences, 17, pp. 658-665, 2013.

[2] P.J. Cárdenas-García, "Does Tourism Growth Influence Economic Development?", Journal of Travel Research, 54 (2), pp. 206-221, 2015.

[3] M.A. Rivera, "The synergies between human development, economic growth, and tourism within a developing country: An empirical mode for Ecuador", Journal of Destination Marketing \& Management, 6 (3), pp.221-232,2017.

[4] S.F. Schubert, J.G. Brida, and W.A. Risso, "The Impact of International Tourism Demand on Economic Growth of Small Economies Dependent on Tourism", Tourism Management, 32 (2), pp. 377-385, 2011.

[5] R. Turner and Z. Sears, "Travel \& Tourism as a Driver of Employment Growth”, World Economic Forum, pp. 63, 2013.

[6] B. Bwalya-Umar and K.H. Mubanga, "Do locals benefit from being in the 'tourist capital'? Views from Livingstone, Zambia", Tourism and Hospitality Research, 18 (3), pp. 333-345, 2016.

[7] Y. Arslanturk, M. Balcilar, and Z.A. Ozdemir, 'Time-Varying linkages between tourism receipts and economic growth in a small open economy’ Economic Modelling, 28 (1-2), pp. 664-671, 2010.

[8] M. Sarusik, Didar Sari, Selahattin Sari, Muhsin Halis, "Tourism sector in order to recovering from the recession: Comparison analyses for Turkey", Procedia - Social and Behavioral Sciences, 24, pp. 181-187, 2011.

[9] Y. Priono, 'Studi Dampak Pariwisata Bukit Batu Kabupaten Kasongan Ditinjau Dari Aspek Ekonomi, Sosial Dan Budaya' Jurnal Perspektif Arsitektur, ISSN 1907-8536, 2011.

[10] Indonesia Investment (2018) 'Tourism Industry Indonesia' www.Indonesia-Investment.com

[11] A. Maulana, 'The Influence of International and Domestic Tourist Visit To Tourism Employment in Indonesia. Jurnal Kepariwisataan Indonesia 11 (1), pp. 119-144, 2016

[12] N. Kim, H. Song, and J.H. Pyun, 'The relationship among tourism, poverty, and economic development in developing countries: A panel data regression analysis' Tourism Economics, 22 (6), pp. 1174-1190, 2016

[13] S. Fredholm, "Assets in the age of tourism: the development of heritage planning in Ghanian Policy", Journal of Contemporary African Studies, 34(4), pp. 498-518, 2016.

[14] United Nations World Tourism Organization (UNWTO), Sustainable Development of Tourism, sdt.unwto.org., 2017.

[15] O. Florin and O. Adeniyi, "Does Tourism Reduce Poverty in SubSaharan African Countries?”, Journal of Travel Research, pp. 1-16, 2019.

[16] D. Qina, H. Xua, and Y. Chung, 'Perceived Impact on The Poverty Alleviation Tourism Policy on The Poor in China' Journal of Hospitality and Tourism Management, 41, pp. 41-50, 2019.

[17] C.N. Jucan and M.S. Jucan, 'Travel and Tourism as a Driver of Economic Recovery' Procedia Economics and Finance, 6 (13), pp. 8188, 2013.

[18] V. Nicula, S. Spanu, and R.E. Neagu, "Regional Tourism Development in Romania - Consistency with Policies and Strategies Developed at EU Level", Procedia Economics and Finance, 6, pp. 530 - 541, 2013.

[19] E. Halpenny, S. Kono, and F. Moghimehfar, 'Predicting World Heritage site visitation intentions of North American park visitors' Journal of Hospitality and Tourism Technology, 9(3), pp. 417-43, 2018.

[20] Y. Poria, A. ReichelAnd A. Biran, 'Heritage Site Perception an Motivation to Visit' Journal of Travel Research, 44, pp. 318-326, 2006. 
[21] S. Serizawa and S. Sunami, "World Heritage Site as the place for education: the case of the Gango-ji Temple in Japan", Asian Education and Development Studies, 2019.

[22] R. Zhanga and L. Smith, 'Bonding and dissonance: Rethinking the Interrelations among Stakeholders in Heritage Tourism' Tourism Management, 74, pp. 212-223, 2019.

[23] P.C. Remoaldo and J.C. Ribeiro, 'Tourists Perception of World Heritage Destinations: The Case of Guimaraes (Portugal)' Tourism and Hospitality Research, vol. 14(4), pp. 206-218, 2014.

[24] X. Yi, V.S. Lin, W. Jin, and Q. Luo, 'The Authenticity of Heritage Sites, Tourists' Quest for Existential Authenticity, and Destination Loyalty' Journal of Travel Research, vol. 56(8), pp. 1032-1048, 2016.

[25] D. Gursoy, 'Residents' perceptions of hotels ' corporate social responsibility initiatives and its impact on residents ' sentiments to community and support for additional tourism development' Journal of Hospitality and Tourism Management, 39, pp. 117-128, 2019.

[26] M. Jaafar, S. Ismail and S.M Rasoolimanesh, "Perceived Social Effects of Tourism Development: A Case Study of Kinabalu National Park", Urban Management, vol. 10(2), pp.-, 2015.

[27] K. Buathong and P.-C. Lai, "Event sustainable development in Thailand: A qualitative investigation", Journal of Hospitality, Leisure, Sport \& Tourism Education, 24, pp. 110-119, 2019.

[28] A. Ahmad, "The Constraints of Tourism Development for a Cultural Heritage Destination: The case of Kampung Ayer (water Village) in Brunei Darussalam", Tourism Management Perspectives, 8, pp. 106113, 2013.

[29] D.L. Edgell, Sr. and J.R. Swanson. Tourism Policy and Planning: yesterday, Today, and Tomorrow, sec. ed, Routledge, 2013.

[30] V. Asero, S. Gocco, and Venetra, "Building Tourism Networks through Tourist Mobility", Journal of Travel Research, vol. 55(6), pp. 751-763, 2015.

[31] C. T€olkes, "The role of sustainability communication in the attitude behaviour gap of sustainable tourism", Tourism and Hospitality Research, pp. 1-12, 2018.

[32] M.Q. Al-Tarawneh and U.V. Osam, "Tourism English training at the tertiary level in Jordan: Reality and expectations from a university context", Journal of Hospitality, Leisure, Sport \& Tourism Education, 24, pp. 155-167, 2019.

[33] F. Pecot and V.D. Barnier, 'Brand heritage: The past in the service of brand management' Recherche et Applications en Marketing, 32 (4), pp. 72-90, 2017.

[34] C. Midgett, C.S. Deale, A. Crawford and M. Weber, "A cross-case analysis of barriers to sustainability in small tourism accommodation enterprises in Dare County, North Carolina”, Tourism and Hospitality Research, pp. 1-13, 2019.

[35] R. Situmorang, "Friend or Foe? The complex relationship between indigenous people and policymakers regarding rural tourism in Indonesia", Journal of Hospitality and Tourism Management, 39, pp. 20-29, 2018

[36] R. Retnosary and F.P. Anggela 'Spinoff Effect of Tourism Attraction to Local Business Performance at Tugu Kebulatan Proklamasi, Rengasdengklok' Journal of Advanced Research in Business and Management Studies, vol. 14(1), pp. 25-34, ISSN: 2462-1935, 2019.

[37] J. Liburd and D. Edwards, "Understanding the sustainable development of tourism", pp. 4,2016

[38] A. Wondirad, D. Tolkach, and B. King, "Stakeholder collaboration as a major factor for sustainable ecotourism development in developing countries", Tourism Management, 78, pp. 104024, 2020

[39] S.-y. Park and T. Kohler, "Collaboration for sustainable tourism through strategic bridging: A case of travel2change", Journal of Vacation Marketing, pp. 1-12, 2018.

[40] R. Musavengane, 'Using the systemic-resilience thinking approach to enhance participatory collaborative management of natural resources in tribal communities: Toward inclusive land reform-led outdoor tourism' Journal of Outdoor Recreation and Tourism, 25, pp. 45-56, 2019.
[41] K. Kousha and M. Thelwall, "Can Google and Mendeley help to assess the scholarly impact of dissertations?," Joournal of Informetrics, vol. 13, pp. 467-484, 2019.

[42] C.A. D'Angelo and S.D. Russo, "Testing for university of Mendeley readership distributions", Journal of Infometrics, vol 13, pp. 726-737, 2019.

[43] N. Comerio and F. strozzi, "Tourism and its economic impact: A literature review using bibliometric tools", Tourism Economic, pp.1-23, 2018.

[44] A, Sangchumnong and M. Kozak, "Sustainable Culture Heritage tourism at Ban Wangke Village, Thailand", Anatolia an International Journal of Tourism and Hospitality Research, pp. 1-11, 2017.

[45] E.C. Soteriou and H. Coccossis, "Integrating Sustainability into the Strategic Planning of National Tourism Organizations", Journal of Travel Research, vol. 49 (2), pp. 191-20, 2010.

[46] IpKin A. Wong, and K.P.Y. Wan, "A Systematic Approach to Scale Development in Tourist Shopping Satisfaction: Linking Destination Attributes and Shopping Experience" Journal of Travel Research, 54(5), pp.672-685,2013.

[47] A. Mrda and B.B. Obad Šćitaroci, "Heritage Touristscapes: A Case study of the Island of Hvar", ANNALES, 26 (3), pp. 553-573, 2016.

[48] T.R. Burns, "Sustainable development: Agents, systems and the environment”. Current Sociology Review. 64 (6), pp. 875-906, 2016.

[49] L. Todd, A. Leask, and John Ensor, "Understanding Primary Stakeholders' Multiple Roles in Hallmark Event Tourism Management", Journal Tourism Management, 2(1), pp. 20-23, 2016.

[50] J. Durkin and M. Peric, "Organising for Community-Base Tourism: Comparing attitudes of local residents and local tourism entrepreneurs in Ravna, Gora, Croatia”, Local Economy, 32 (7), pp. 678-69, 2017.

[51] D. Lin and D. Simmons, "Structured inter-network collaboration; public participation in tourism planning in Southern China", Tourism Management, vol. 63, pp. 315-328, 2017.

[52] H. Saito and L. Ruhanen, "Power in tourism stakeholder collaborations Power types and power holders", Journal of Hospitality and Tourism Management, 31, pp. 189-196, 2017.

[53] J. Surinach and K. Wo, "Introduction to the special focus: Cultural tourism and sustainable urban development", Tourism Economics, 23 (2), pp. 239-242, 2017.

[54] Daisy X.F.F., Hanqin Q. Zhang, Carson L. Jenkins, and Pearl M.C. Lin, "Does Tourist-Host Social Contact Reduce Perceived Cultural Distance?”, Journal of Travel Research, 56 (8), pp. 998-1010, 2017.

[55] A.G. Asmelash and S. Kumar, "The structural relationship between tourist satisfaction and sustainable heritage tourism development in Tigrai Ethiopia”, Heliyon, vol. 5, 2018.

[56] D.S. Blundo, A.M. Ferari, M. Pini, M.P. Riccardi, J.F. Garcia, and A.P.F. del Hoyo, "The Life Cycle Approach as an Innovative Methodology for The Recovery and Restoration of Cultural Heritage", Journal of Cultural Heritage Sustainable Development, vol. 4(2), pp. 133-148, 2013.

[57] J. Almeida, C. Costa and F. Nunes da Silva, "Collaborative approach for tourism conflict management: A Portuguese case study", Land Use Policy, 75, pp. 166-179, 2018.

[58] J.S. Horng and C.T. (Simon) Tsai, "Government websites for promoting East Asian culinary tourism: A cross-national analysis" Tourism Management, 31(1), pp. 74-85, 2010.

[59] S. Yousaf and F. Xiucheng, "Halal culinary and tourism marketing strategies on government websites: A preliminary analysis" Tourism Management, 68, pp. 423-443, 2018.

[60] T. Baum and E. Szivas," HRD in tourism: A role for government?' Tourism Management, 29(4), pp. 783-794, 2008

[61] A.D. Alonso, and J. Nyanjom, "Local Stakeholder, Role and Tourism Development", Current Issue in Tourism, 20(5), pp. 480-496, 2015.

[62] Y. Wang and B. Bramwell, "Heritage protection and tourism development priorities in Hangzhou, China: A political economy and governance perspective", Tourism Management, vol. 30, pp. 988-998, 2012. 